\title{
THE EU'S SINGLE RESOLUTION BOARD: AN EU AGENCY BUILT ON SAND OR ON A ROCK?
}

\author{
Ana Kozina, Stefan Martinić, Vedrana Mihalić*
}

\begin{abstract}
Summary: The main topic of this paper is the validity of the establishment of an EU agency, the Single Resolution Board, ie whether it was created on a valid legal basis in accordance with the Treaty of Lisbon. More broadly, but also on a smaller scale, the topic of the paper is also whether the creation of an EU agency, such as the SRB, is a prime example of transition from a system of EU vertical federalism to a system of EU horizontal federalism and whether that transition is in accordance with the constitutional framework of the EU. The paper will also give an explanation of the three stages of the European Banking Union, the term 'resolution', and a brief overview of the SRB.
\end{abstract}

\section{Introduction: the research problem, its background and the structure of the paper}

'Everyone therefore who hears these words of mine, and does them, I will liken him to a wise man, who built his house on a rock. The rain came down, the floods came, and the winds blew, and beat on that house; and it didn't fall, for it was founded on the rock. Everyone who hears these words of mine, and doesn't do them will be like a foolish man, who built his house on the sand. The rain came down, the floods came, and the winds blew, and beat on that house; and it fell - and great was its fall.'1

This paragraph from the Gospel of Matthew is about wise and foolish builders. This paper will, in essence, analyse whether the EU acted as a wise builder when it built the Single Resolution Board (hereinafter: 'SRB' or 'the Board').

The builders of the principal building of the European Parliament in Strasbourg, France, the Louise Weiss building, intended it to carry heavy

The authors are fifth-year students at the Faculty of Law of the University of Zagreb. We would like to express our gratitude to our mentor Jean Monnet Professor Tamara Ćapeta for her support, guidance and help through the preparation of this paper. Without her help, this paper would not have been possible. We would also like to thank the entire Chair of European Public Law at the University of Zagreb for their creative ideas, suggestions for various sources of information during the European Law Moot Court Competition on the topic of the European Banking Union which inspired us to write this paper, and for allowing us to borrow a large amount of literature.

1 Matthew 7:24-27, Revised Standard Version of the Bible. 
symbolism. ${ }^{2}$ Its voluntarily unfinished aspect of the tower symbolises the unfinished work of European integration. ${ }^{3}$ It paints the European Union as work in progress.

The fact that the European Union is an unfinished project was evident during the banking, financial, economic and sovereign debt crisis that struck in 2008. ${ }^{4}$ When the crisis hit, every Member State (hereinafter: MS) tried to solve the ongoing crisis on its own. ${ }^{5}$ Such an individual approach by each MS created a phenomenon that is, basically, a neverending circle, making the solvency of an MS connected with the solvency of banks, causing the MSs to be vulnerable to the spill-over effect from their banking sectors. ${ }^{6}$

As a consequence of the sovereign debt crisis, in 2012 the EU created the European Banking Union (hereinafter: EBU). ${ }^{7}$ The EBU provides

2 André M Winter, [photograph of Louise Weiss Building, Seat of the European Parliament in Strasbourg] (Cartographers on the Net, 10 August 2008) <www.carto.net/andre.mw/ photos/2008/10/08_strasbourg/20081008-143946_louise_weiss_building_seat_of_the_ european_parliament_in_strasbourg.shtml> accessed 10 February 2017.

3 Winter (n 2).

4 To find out more on the banking, financial and economic crisis in 2008, see also, "The Origin of the Financial Crisis; Crash Course' The Economist (London, 7 September 2013) $<$ www.economist.com/news / schoolsbrief/2 1584534-effects-financial-crisis-are-stillbeing-felt-five-years-article> accessed 10 March 2017; Frederic S Mishkin, 'Over the Cliff: From the Subprime to the Global Financial Crisis' (2011) 25(1) Journal of Economic Perspectives <www.aeaweb.org/articles?id=10.1257/jep.25.1.49> accessed 10 March 2017; Nicholas H Dimsdale, 'The Financial Crisis of 2007-9 and the British Experience' (2009) 4 Oxonomics

<http://onlinelibrary.wiley.com/doi/10.1111/j.1752-5209.2009.00026.x/pdf>accessed 12 March 2017.

5 Aitor Erce 'Bank and Sovereign Risk Feedback Loops' (2015) Globalization and Monetary Policy Institute Working Paper 227 <www.dallasfed.org/assets/documents/institute/wpapers/2015/0127.pdf> accessed 15 March 2017.

6 The financial and economic crisis started in 2008 with the failure of the largest banks in Iceland, and from there the sovereign debt crisis spread to the MSs of the EU, namely Greece, Ireland and Portugal in 2009 and Italy in 2010. In 2009, Greece announced that it had been understating its deficit figures for years, which consequently led to shutting Greece out from borrowing in the financial markets. In 2010 Greece was heading for bankruptcy and the EU discovered that the Greek government had effectively hidden its actual level of borrowing to be able to spend beyond its means and appear to maintain the required criteria to remain in the Eurozone. It soon became clear that the Greek government could not resolve the crisis on its own, especially since its credit rating in spring 2010 fell to junk level. It was impossible for the Greek government to bailout its banking system without aid. The concern spread from Greece to other highly indebted countries, given that the Maastricht criteria set out that an MS in the Eurozone should have a budget deficit below 3\%; in 2010, it was $13 \%$ in Greece, $11.4 \%$ in Spain, and in Portugal 9.3\%. For more on the Eurozone MS economic crisis, see Franco Praussello, 'How Eurozone Member Countries Did Not Succeed in Fixing the Sovereign Debt Crisis' in Franco Praussello (ed), The Eurozone Experience: Monetary Integration in the Absence of a European Government (FrancoAngeli 2012) 15.

7 Douglas Elliot, 'Key Issues on European Banking Union; Trade-Offs and Some Recommendations' (2012) Brookings Institute Global Economy and Development 11/2012 52 <www.brookings.edu/wp-content/uploads/2016/06/11-european-banking-union-elliott. pdf> accessed 26 March 2017. 
a strong and centralised system of supervision and resolution ${ }^{8}$ that has both the authority and the power to restore the stability of the Eurozone's banking system and break the vicious circle between sovereign states and banks. ${ }^{9}$ Its aim is to put an end to the era of massive bailouts ${ }^{10}$ paid for by taxpayers and to help restore financial stability. ${ }^{11}$ Moreover, the objective of the EBU is to create the right conditions for the financial sector to lend to the real economy, spurring economic recovery and job creation. ${ }^{12}$

A crucial institution within the EBU and the main focus of this paper is the independent EU Agency called the Single Resolution Board ('SRB' or 'the Board'). The SRB was established by Regulation (EU) No 806/2014 on the Single Resolution Mechanism (hereinafter: SRM Regulation). ${ }^{13}$ The SRM Regulation implements the EU-wide Bank Recovery and Resolution Directive (hereinafter: BRRD) in the euro area. ${ }^{14}$ The SRM Regulation was

\footnotetext{
8 According to the Council Directive 2014/59/EU of 15 May 2014 establishing a framework for the recovery and resolution of credit institutions and investment firms and amending Council Directive 82/891/EEC, and Directives 2001/24/EC, 2002/47/EC, 2004/25/ EC, 2005/56/EC, 2007/36/EC, 2011/35/EU, 2012/30/EU and 2013/36/EU, and Regulations (EU) No 1093/2010 and (EU) No 648/2012, of the European Parliament and of the Council [2014] OJ L173 190 (hereinafter: BRRD), a resolution is a procedure, an alternative to bankruptcy proceedings, inured to ensure that the liquidation of banks is orderly, through a competent authority. See also European Commission Memo (European Commission, 15 April 2014) <http://europa.eu/rapid/press-release_MEMO-14-297_en.htm> accessed 9 March 2017.

9 Upon creating the EBU with its supervisory and resolution powers, only the Eurozone MSs would automatically be under its governance, whilst other EU MSs that are not part of the Eurozone can opt to enter. See also Eilis Ferran, 'European Banking Union: Imperfect, But It Can Work' in Danny Busch and Guido Ferrarini (eds), European Banking Union (OUP 2015) 80.

10 A bailout is a situation in which a business, an individual or a government offers money to a failing business to prevent the consequences that arise from the business's downfall. Bailouts have traditionally occurred in industries or businesses that are perceived as no longer being viable or are sustaining huge losses. See also 'Bailout' Investopedia, <www.investopedia.com/terms/b/bailout.asp> accessed 13 April 2017; for example, in spring 2010, when it became evident that the Greek government would not be able to bailout its failing system, it called in the so-called troika - the International Monetary Fund, the European Central Bank and the European Commission. The troika issued the first of two international bailouts for Greece, which would eventually total more than $€ 240$ billion. The bailouts came with conditions, such as deep budget cuts and steep tax increases. See also Praussello (n 6) 20.

11 Jean Pisani-Ferry, André Sapir, Nicolas Véron and Guntram Wolff, 'What Kind of European Banking Union?' (2012) 12 Bruegel Policy Contribution <http://bruegel.org/wp-content/uploads/imported/publications/pc_2012_12_Banking.pdf> accessed 5 April 2017.

12 Fritz Breuss, 'European Banking Union' (2013) WIFO Working Papers 336/2013, 454 $<$ http://fritz.breuss.wifo.ac.at/Breuss_European_Banking_Union_WIFO_WP_454_ Sept_2013.pdf> accessed 20 February 2017.

13 Council Regulation (EU) 806/2014 of 15 July 2014 establishing uniform rules and a uniform procedure for the resolution of credit institutions and certain investment firms in the framework of a Single Resolution Mechanism and a Single Resolution Fund and amending Regulation (EU) No 1093/2010 [2014] OJ L225/1.

14 BRRD (n 8). For more on the BRRD, see European Commission, 'Single Resolution Mechanism to Come into Effect for the Banking Union' (Press Release) IP/15/6397 <http:// europa.eu/rapid/press-release_IP-15-6397_en.htm> accessed 15 March 2017.
} 
adopted on the basis of article 114 of the Treaty on the Functioning of the European Union (hereinafter: TFEU). ${ }^{15}$

The SRB strives to become a trusted and respected resolution authority with a strong resolution capacity and the ability to act swiftly and in an appropriate, consistent and proportionate manner in establishing and enforcing an effective resolution regime for ailing banks in the Single Resolution Mechanism jurisdictions, thus avoiding future taxpayer bailouts. ${ }^{16}$

The role of the Board is proactive: it focuses on resolution planning and preparation with a forward-looking mindset to avoid the potential negative impact of a bank failure on the real economy, financial stability and the public finances of the participating $\mathrm{MSs}^{17}$ of the EBU. ${ }^{18}$

But, unfortunately, the June 2017 the cases of Italian banks Banca Popolare di Vicenza and Veneto Banca, as well as Monte dei Paschi di Siena which is being saved through a publicly funded 'precautionary recapitalisation', sends a clear signal that public coffers are still fair game for aiding failing banks. ${ }^{19}$

Even though at first glance it may seem that the Board has been created in the EU citizens' best interests, we need to keep in mind the old saying that sometimes the road to hell is paved with good intentions. It may not signify that anything is worrisome in this particular case, but the authors would like to analyse the debate surrounding the Board and present their conclusions and arguments on the matter.

The main topic of this paper is the validity of the establishment and the empowerment of the SRB, ie whether it was created on a valid legal basis in accordance with the Treaty of Lisbon. More broadly, but also on a smaller scale, the topic of the paper is whether the creation of an EU agency (the SRB) is a prime example of transition from a system of EU vertical federalism to a system of EU horizontal federalism ${ }^{20}$ and whether

15 Consolidated Version of the Treaty on European Union [2016] OJ C202.

16 Single Resolution Board Mission (Single Resolution Board) <https://srb.europa.eu/en/ mission> accessed 14 March 2017.

17 Upon creating the EBU with its supervisory and resolution powers, only the Eurozone MSs would automatically be under its governance, whilst other EU MSs that are not part of the Eurozone can opt to enter. For more on MS participation, see Giuseppe Boccuzzi, The European Banking Unit: Supervision and Resolution (Palgrave Macmillan Studies in Banking and Financial Institutions 2016).

18 Single Resolution Board Mission <https://srb.europa.eu/en/mission> accessed 14 March 2017.

19 For more on Banca Popolare di Vicenza and Veneto Banca, see Fiona Maxwell, 'Italy Tests EU's New Rules, Again' (Politico, 26 June 2017) <http:/ /www.politico.eu/article/italytests-eu-new-bank-rules-veneto-banca-popolare-di-vicenza/> accessed 1 August 2017.

20 The structure of EU federalism combines vertical federalism, ie vertical allocation/distribution of power (between EU institutions and Member States) with horizontal federalism, ie 
that transition is in accordance with the constitutional framework of the EU. Before specifying the main question of the paper, more context to the topic will be provided.

The EU is (or was until the EU agencies started to develop) a system of so-called vertical federalism. ${ }^{21}$ This means that even though the EU has wide regulatory powers, the implementation and enforcement of those powers happens at the level of MSs. ${ }^{22}$ In a way, the EU level of governance is not self-sufficient. It may not function without the cooperation of bodies in the MSs. In contrast, in the US or Canada, for example, there is a system of horizontal federalism. ${ }^{23}$ This means that each federal piece of legislation can be implemented and enforced by the agency established also at the federal level. ${ }^{24}$ Thus, the federal level is self-sufficient and the implementation of federal policies does not depend on MS willingness to enforce them (in the US, this is even prohibited; the federation cannot order the states to implement federal law, so-called 'no commandeering'). ${ }^{25}$

In the EU, vertical federalism is provided for in the Treaties, where article 291 TFEU provides that implementation happens in the MS. Only if necessary for the sake of uniformity may the Commission enact common implementing rules. However, with the establishment of regulatory agencies this changes, and the EU also becomes independent of MS authorities.

Article 114 TFEU, on which the SRB was established, can be invoked to establish an EU agency under the condition that the creation of such an EU agency will improve the functioning of the internal market. ${ }^{26} \mathrm{On}$

horizontal allocation/distribution of power (between institutions at the EU level). In other words, it combines federalism with its own brand of separation of powers.

Vertical federalism is how power is or should be allocated between the federal and state tiers of government, and how to prevent the federal and state governments from encroaching on each other's prerogatives.

For more on the structure on EU federalism, see R Daniel Kelemen, 'The Structure and Dynamics of EU Federalism' (2003) 36 Comparative Political Studies 184 <http://fas-polisci. rutgers.edu/dkelemen/research/Kelemen_StructureAndDynamicsOfEUFederalism.pdf> accessed 17 March 2017; Allan Erbsen, 'Horizontal Federalism' (2008) 93 Minnesota Law Review 493 <http://scholarlycommons.law.case.edu/cgi/viewcontent.cgi?article=1042\&con text=caselrev> accessed 18 March 2017. EU horizontal federalism is a horizontal allocation/ distribution of power between different institutions, bodies and agencies at the EU level. See Kelemen (n 20) 184-271.

21 Gregory A Caldeira, 'Comparative Federalism and the Role of the Judiciary' in Keith E Whittington, R Daniel Kelemen (eds), The Oxford Handbook of Law and Politics (OUP 2010).

22 ibid 1-14.

23 ibid 1-14.

24 Jeffrey N Gordon and Wolf-Georg Ringe, 'Bank Resolution in the European Banking Union: A Transatlantic Perspective on What It Would Take' (2015) 115 Columbia Law Review 1297.

25 Gordon and Ringe (n 24).

26 Case C 217/04 United Kingdom of Great Britain and Northern Ireland $v$ European Parliament and Council of the European Union (ENISA) ECLI:EU:C:2006:279, para 42. 
the basis of article $114 \mathrm{TFEU}$, the SRB was given the power to arrange the resolution of certain ailing banks, a right that was up to now reserved for MSs and their National Resolution Authorities (hereinafter: NRAs). ${ }^{27}$

The creation of the SRB with such power is, in fact, an act of taking away implementing powers from the MSs, even though the implementing powers are reserved by the Treaty of Lisbon for the MSs, except in exceptional circumstances. ${ }^{28}$ Such a transfer of implementing powers was justified by invoking the gains for the internal market.

Therefore, having in mind the principle of conferral of powers, ${ }^{29}$ upon which the Union is based, the question is whether article 114 TFEU is a valid legal basis for the establishment of such an EU agency, and whether this is an example of transition from the system of EU vertical federalism to a system of EU horizontal federalism (under the pretext of internal market benefits).

The transfer of implementing powers from the national level to the EU level represents an example of transition from the system of EU vertical federalism to a system of EU horizontal federalism because there is a transition from a separation of different implementing powers between EU institutions and Member States (vertical federalism) to a separation of implementing powers between different institutions, bodies and agencies at the EU level (horizontal federalism). ${ }^{30}$

This argumentation and the relevance of the notion of federalism becomes clearer when one keeps in mind the relation between vertical

27 Resolution authorities are the authorities in each Member State that are empowered to apply the resolution tools and exercise the resolution powers. In addition to the resolution authorities, competent ministries are also designated in the Member States, which are responsible for economic, financial and budgetary decisions at the national level according to national competences and which have been designated in each Member State as ministries responsible for exercising the functions of the competent ministries. Resolution authorities empowered to exercise resolution powers and apply the resolution tools are the Croatian National Bank, the Croatian Financial Services Supervisory Agency and the State Agency for Deposit Insurance and Bank Resolution. See, also, Resolution Authorities (Hrvatska Narodna Banka 2016)

<https://www.hnb.hr/en/core-functions/resolution/resolution-authorities> accessed 20 March 2017.

28 TFEU (n 15) art 291.

29 Under this fundamental principle of EU law, laid down in Article 5 of the Treaty on European Union, the EU acts only within the limits of the competences that EU countries have conferred upon it in the Treaties. These competences are defined in Articles 2-6 of the Treaty on the Functioning of the EU. Competences not conferred on the EU by the Treaties thus remain with EU countries. While the principle of conferral governs the limits to EU competences, the use of those competences is governed by the principles of subsidiarity and proportionality. See Conferral (EUR-Lex Access to European Union Law)

<http:/ / eur-lex.europa.eu/summary/glossary/conferral.html> accessed 13 April 2017.

30 For more on EU vertical and horizontal federalism, see Kelemen (n 20) 184-271. 
and horizontal federalism on the one hand and the principle of conferral and the principle of institutional balance ${ }^{31}$ on the other hand. These concepts are interlinked and have equivalent importance in an analysis of the architecture of the EU's institutions and their pertaining powers. However, there is a relevant difference in the sense that the concept of vertical and horizontal federalism is used primarily to describe the allocation/distribution of power (between EU institutions and the MSs), while the concepts of the principle of conferral and the principle of institutional balance are primarily used to govern the limits to competences between different EU institutions and MSs. In other words, the latter concepts are actually used as a justification based in the Treaty for the attribution of certain powers to a certain EU institution, or juxtaposed as a test of whether the legality of the attribution of a power to an institution would come into question. The former concept of different types of federalism, on the other hand, is used simply to factually explain the different allocation of competences, ie power, in different systems of government.

The Treaty of Lisbon, in its article 114(1), envisaged the possibility of the adoption 'of measures for the approximation of the provisions laid down by law, regulation or administrative action in Member States which have as their object the establishment and functioning of the internal market'. ${ }^{32}$ The logic could be illustrated as follows: if the establishment of the SRB fulfils the conditions laid down in article 114 TFEU, then there cannot be claims of an infraction of the principle of conferral or of an unconstitutional breach of the principle of institutional balance. Only if the conditions of article $114 \mathrm{TFEU}$ are not satisfied can there be a deeper investigation and discussion of whether the principles of conferral and/ or the principle of institutional balance have been under assault. This is because the MSs, by ratifying the Treaty of Lisbon, have accepted the possibility that article 114 TFEU will be used for the adoption of measures if its conditions are met; thus, EU countries cannot claim that the EU acts outside its competences since they conferred this competence upon it in

31 The principle of institutional balance in the EU implies that each of its institutions has to act in accordance with the powers conferred on it by the Treaties, in accordance with the division of powers. The principle derives from a 1958 judgment by the Court of Justice (the Meroni judgment) and prohibits any encroachment by one institution on the powers of another. It is the responsibility of the Court of Justice of the European Union to ensure that this principle is respected. Put at its simplest, for example, this refers to the relationship between the three main EU institutions: the European Parliament, the Council of the European Union and the European Commission. The dynamics between these bodies have evolved considerably over the years with the adoption of new treaties. The competences of the European Parliament, in particular, have expanded, giving it the right of co-decision with the Council (under the ordinary legislative procedure) in the majority of EU policy areas, as well as wider budgetary powers. See EUR-lex Institutional Balance

$<$ http://eur-lex.europa.eu/summary/glossary/institutional_balance.html> accessed 20 April 2017.

32 Consolidated Version of the Treaty on European Union [2016] OJ C202. 
the first place.

Therefore, examination will be made on whether or not the EU institutions are changing EU federalism as envisaged by the Treaty of Lisbon because of the needs of the moment and against the provisions of TFEU and the fundamental principle of conferral. If so, how can this be seen as constitutional?

While discussing the constitutionality of the alleged changing of EU federalism, the debate will be limited to the situation surrounding the $\mathrm{SRB}$, as a complete analysis of (the transition of) EU federalism goes beyond the scope of this paper.

There is no denying that there is an economic, financial and political need for the on-going construction of the European project. ${ }^{33}$ However, the development of the EU's agencies and its administrative landscape, as well as transition from a system of EU vertical federalism to EU horizontal federalism, needs to withstand the scrutiny of the rule of law.

Any development of the European project that would be based contrary to the ratified Treaty of Lisbon would be built on sand, as it would only embolden the growing Eurosceptic sentiment throughout the Continent. Such a cautious stance is not a novel idea, since there have been many articles and discussions on whether judicial activism can be a vehicle of democratic deficit and Euroscepticism. ${ }^{34}$

There is concern over the sound legal basis for adopting the SRM Regulation (an important foundation for the EBU, which also established the SRB) expressed, for example, by the German Minister of Finance (since 2009) Wolfgang Schäuble. ${ }^{35}$ A letter from Germany's chief banking union negotiator, Mr. Schäuble, to the then EU Commissioner for Internal Market and Services, Michel Barnier, written on 11 July 2013, reveals significant scepticism over the appropriateness of article 114 TFEU as a sound legal foundation of the EBU and SRB. ${ }^{36}$

Unfortunately, the SRB is not the only EU agency concerning which there is scepticism over its legal foundations. In May 2012, the United

\footnotetext{
33 In June 2015, the Five Presidents issued a report on the state of the EBU, emphasising the need for its completion on the way to achieving the singular monetary policy and its implementation and execution in the Eurozone MSs. See The Five Presidents' Report, 'Completing Europe's Economic and Monetary Union' (European Commission, 22 June 2015) <https://ec.europa.eu/info/system/files/factsheet-completing-banking-union-21102015_ en.pdf $>$ accessed 17 April 2017.

34 See, for instance, JHH Weiler, The Political and Legal Culture of European Integration: An Exploratory Essay (2011) 9(3-4) International Journal of Constitutional Law 678.

35 Klaus C Engelen, 'Questionable Legality' (2014) The Magazine of International Economic Policy 38 <http://www.international-economy.com/TIE_Su14_Engelen.pdf> accessed 17 April 2017.

36 Letter from Wolfgang Schäuble to Michel Barnier (11 July 2013).
} 
Kingdom brought an action before the Court of Justice of the European Union (hereinafter: the Court) seeking the annulment of article 28 of Regulation (EU) No 236/2012 of the European Parliament and of the Council of 14 March 2012 on short selling and certain aspects of credit default swaps (OJ 2012 L86/1) (hereinafter: Short Selling Regulation). ${ }^{37}$ The United Kingdom submitted that article 114 TFEU was not the correct legal basis for the adoption of the rules laid down in article 28 of the Regulation. ${ }^{38}$ The United Kingdom also contended, inter alia, that an EU agency, the European Securities and Markets Authority (hereinafter: ESMA) had been given a very large measure of discretion of a political nature which was at odds with EU principles relating to the delegation of powers. ${ }^{39}$

Although Advocate General (hereinafter: AG) Niilo Jääskinen proposed that article 28 of the Regulation be annulled on the grounds that article 114 TFEU was not a proper legal basis for its adoption, ${ }^{40}$ the Court took a different view. ${ }^{41}$ The Court took a view in favour of the EU agency, ie ESMA, and such a position of the Court is regarded as a controversial one in academia (see more on the ESMA case in subsection 3.2 below).$^{42}$

Hence, because of the debate and the differing opinions in academia, in the European institutions,${ }^{43}$ in national governments, ${ }^{44}$ etc, the authors believe that there is controversy and open questions about the limits of article 114 TFEU as the legal basis for the creation of the SRB and

\footnotetext{
37 Case C 270/12 United Kingdom of Great Britain and Northern Ireland $v$ European Parliament and Council of the European Union (ESMA) ECLI:EU:C:2014:18.

38 Regulation (EU) No 236/2012 of the European Parliament and of the Council of 14 March 2012 on short selling and certain aspects of credit default swaps OJ [2012] L 86/1, paras 88-90 <http://eur-lex.europa.eu/LexUriServ/LexUriServ.do?uri=OJ:L:2012:086:00 01:0024:en:PDF> accessed 24 March 2017.

39 Regulation (EU) No 236/2012 (n 38) paras 28-34.

40 Case C-270/12 United Kingdom of Great Britain and Northern Ireland $v$ European Parliament and Council of the European Union [2012] ECLI:EU:C:2013:562, Opinion of AG Jääskinen <http://curia.europa.eu/juris/document/document.jsf?docid=140965\&doclang=EN> accessed 13 April 2017.

41 ESMA (n 34) para 119.

42 See also, Phedon Nicolaides and Nadir Preziosi, 'Discretion and Accountability: The ESMA Judgment and the Meroni Doctrine' (2014) Bruges European Economic Research Papers 30/2014 <http:/ / aei.pitt.edu/57214/> accessed 14 April 2017; Simone Gabbi, 'The Principle of Institutional (Un)Balance after Lisbon' (2014) 5(2) European Journal of Risk Regulation 259; Niamh Moloney, EU Securities and Financial Markets Regulation (3rd edn, OUP 2014); Marta Simoncini, 'Legal Boundaries of European Supervisory Authorities in the Financial Markets: Tensions in the Development of True Regulatory Agencies' (2015) 34 YEL 319.

43 Alex Barker, 'Setback for Brussels as Lawyers Warn on Banking Union Plans' Financial Times (London, 2013) < https://www.ft.com/content/306c4e48-2ffe-11e3-9eec-00144feab7de> accessed 3 February 2017.

44 For more on national governments' debate on the scope of art 114 TFEU, see Alex Barker, 'Blow to German Banking Union Plan' Financial Times (London, 2013) <https://www. ft.com/content/ea7c2eb6-1b90-11e3-94a3-00144feab7de> accessed 3 February 2017.
} 
similar current and future EU agencies, as well as for the ongoing 'agencification'45 of the EU, or what other authors vividly call the 'mushrooming of EU agencies'. ${ }^{46}$ The authors would like to emphasise that some doctrines have considered the SRB to be built on sand. However, from this standpoint it is important not to take the surrounding controversy at face value, but to dissect it, elaborate a potential different approach and to conclude whether or not the criticism of the founding of such an important EU agency is persuasive.

Therefore, this paper will analyse two main questions:

1. Was Article 114 TFEU a valid legal basis for the adoption of the SRM Regulation by which the EU agency 'Single Resolution Board' was established?

2. In a broader perspective, but also on a smaller scale, is this an example of transition from a system of EU vertical federalism to a system of EU horizontal federalism, and is it in accordance with the constitutional framework of the EU?

In section 2 below, an explanation will be given of the three stages of the EBU, the term 'resolution' and a brief overview of the SRB in order to allow readers to understand the key features and logic behind their establishment.

In section 3, a general overview of the EU agencies will be given at the outset, and then an analysis will be made of (i) the appropriateness of using article 114 TFEU to centralise a resolution mechanism; (ii) the appropriateness of setting up an agency with centralised implementing powers on the basis of article 114 TFEU; and (iii) in general terms, whether the EU principle of conferral has been breached.

\footnotetext{
45 'Agencification refers to the creation of semi-autonomous organizations that operate at arms' length of the government, to carry out public tasks (regulation, service delivery, policy implementation) in a relatively autonomous way ie there is less hierarchical and political influence on their daily operations, and they have more managerial freedoms. There is much controversy over the definition of agencies but a consensus has grown that an "agency" in terms of agencification is an organization that (i) is structurally disaggregated from the government and (ii) operates under more business-like conditions than the government bureaucracy. Agencies can for example have a different financial system and personnel policies, although the degrees of financial, personnel, and management autonomy vary per (type of) organization. It is exactly this degree of variation between (types of) organizations that make it impossible to develop a more precise definition.' See Herwig CH Hofmann and Alessandro Morini, 'Constitutional Aspects of the Pluralisation of the EU Executive Through "Agencification"' (2012) 37(4) European Law Review 419.

46 See Madalina Busuioc, 'Accountability, Control and Independence: The Case of European Agencies' (2009) 15 European Law Journal 600; Anne Meuwese, Ymre Schuurmans and Wim Voermans, 'Towards a European Administrative Procedure Act?' (2009) Review of European Administrative Law 16.
} 
Lastly, section 4 will draw conclusions and answer the main questions of the paper.

\section{The Single Resolution Board: the why and the how behind it}

In order for readers to understand the discussions in this paper, this section will give a brief explanation of the three stages of the European Banking Union, the term 'resolution' and the SRB and its powers.

\subsection{Three stages of the European Banking Union (EBU)}

As mentioned above, the idea of the EBU came about as a consequence of the sovereign debt crisis. The heads of state and government had in June 2012 agreed upon creating a banking union, a new framework and a means of completing the monetary and economic union. ${ }^{47}$ The original plan was to create a thriving economic, monetary and banking union whose foundations would stand on four pillars built in the following three stages: ${ }^{48}$

- Single Supervisory Mechanism (SSM);

- Single Resolution Mechanism (SRM);

- European Deposit Insurance Scheme (EDIS). ${ }^{49}$

These three stages are all interconnected and are overlaid by the Single Rulebook that sets up the framework and is the legal basis of the EBU. ${ }^{50}$

In the first stage, there was a transfer of the responsibility of banking supervision from the national authorities to the ECB as the centre from

\footnotetext{
47 'A single banking system is the mirror image of a single money. As the vast majority of money is bank deposits, money can only be truly single if confidence in the safety of bank deposits is the same irrespective of the Member State in which a bank operates. This requires single bank supervision, single bank resolution and single deposit insurance.' See The Five Presidents' Report (n 33).

48 The four pillars upon which the EBU should be built are: an integrated financial framework, an integrated budgetary framework, an integrated economic policy framework to ensure growth, employment and competitiveness, and ensuring democratic legitimacy and accountability in decision-making in the EMU, whilst the three stages in which to do it are: a single supervisory mechanism, a single resolution mechanism and a single deposit guarantee mechanism. See also Breuss (n 12) 454.

49 Erik Berglöf, Ralph De Haas and Jeromin Zettelmeyer, 'Banking Union: The View from Emerging Europe' (2012) VOX CEPR's Policy Portal <http://voxeu.org/article/bankingunion-view-emerging-europe> accessed 15 April 2017.

50 Council Regulation (EU) 575/2013 of 26 June 2013 on prudential requirements for credit institutions and investment firms and amending Regulation (EU) No 648/2012 [2012] OJ L176/ 1 (CRR Regulation); Council Directive 2013/36/EU of 26 June 2013 on access to the activity of credit institutions and the prudential supervision of credit institutions and investment firms, amending Directive 2002/87/EC and repealing Directives 2006/48/EC and 2006/49/EC [2013] OJ L176/338 (hereinafter: CRD IV Directive).
} 
which the EBU started its formation. ${ }^{51}$ The Single Supervisory Mechanism (hereinafter: SSM) was set up and became fully operational in November 2014 when the ECB achieved its supervisory tasks. ${ }^{52}$

The second stage includes: a new set of rules governing the resolution of troubled banks, as laid down in the BRRD; a new authority - the Single Resolution Board which holds resolution powers; and the Single Resolution Fund (hereinafter: SRF) which is entrusted with financial resources pooled together across the euro area countries. ${ }^{53}$ The new rules and the Board have been running since January 2016, without the SRF, which is going to be built gradually during a transition period that will end in $2024 .{ }^{54}$

The third stage is currently missing, since the Directive on Deposit Insurance approved in 2014 is still a harmonisation device, and it does not introduce any common guarantee scheme across the Eurozone MSs. ${ }^{55}$

To sum up, the then newly formed banking union was to develop through three stages. The first stage involves the establishment of the SSM to provide supervision for the entire Eurozone. ${ }^{56}$ The second stage is the establishment of the SRM with the SRB that decides whether a financial institution under supervision came to the point where it needs to be resolved. ${ }^{57}$ And the third stage is the establishment of the EDIS that provides a safety net for the financial institutions undergoing restructuring and resolution. ${ }^{58}$

\footnotetext{
51 Berglöf, De Haas and Zettelmeyer (n 49).

52 Council Regulation (EU) 1024/2013 of 15 October 2013 conferring specific tasks on the European Central Bank concerning policies relating to the prudential supervision of credit institutions [2013] OJ L287/63 (hereinafter: SSM Regulation). Related changes were made when the ECB achieved its supervisory tasks through the Memorandum of Understanding between the Council and the ECB on practical aspects of the exercise of democratic accountability of the supervisory tasks of the ECB vis-à-vis the Council (December 2013); the Inter-institutional Agreement covering practical aspects of the exercise of democratic accountability of the supervisory tasks of the ECB vis-à-vis the European Parliament (November 2013); Regulation EU 468/2014 of the European Central Bank of 16 April 2014 establishing the framework for cooperation within the single Supervisory Mechanism between the European Central Bank and national competent authorities and with national designated authorities [2014] OJ L141/1 (hereinafter: SSM Framework Regulation); Regulation (EU) 469/2014 of the European Central Bank of 16 April 2014 amending Regulation (EC) 2157/1999 on the powers of the European Central Bank to impose sanctions (ECB/1999/4) [2014] OJ L141/51.

53 SSM Regulation (n 52).

54 SSM Framework Regulation (n 52).

55 Angelo Baglioni, The European Banking Union: A Critical Assessment (Palgrave Macmillan Studies in Banking and Financial Institutions 2016).

56 Daniel Gros and Dirk Schoenmaker, 'European Deposit Insurance and Resolution in the Banking Union' (2014) 52(3) Journal of Common Market Studies 529 <http: / / onlinelibrary. wiley.com/wol1/doi/10.1111/jcms.12124/full> accessed 14 April 2017.

57 ibid.

58 ibid.
} 


\subsection{The resolution of ailing banks}

As already stated, the SRB is an EU agency in charge of handling bank and other financial institution resolutions. 'Resolution' is the main right, duty and preoccupation of the SRB. Hence, before one defines the SRB and its powers, one needs to define the term 'resolution'.

According to the BRRD, ${ }^{59}$ a resolution is a procedure, an alternative to bankruptcy proceedings, ${ }^{60}$ implemented to ensure that the liquidation of banks is orderly, through a competent authority. ${ }^{61}$ Its aim is to prevent the failure of a given bank from evolving into a systemic banking crisis and to minimise the cost to taxpayers for supporting banks. ${ }^{62}$ Resolution occurs at the point when the authorities determine that a bank is failing or likely to fail, when no other private sector intervention could bring the institution back to viability within a set timeframe and when the usual insolvency proceedings ${ }^{63}$ would lead to financial instability. ${ }^{64}$

Resolution is an essential complement to other EBU tools designed to make the financial system sounder, eg making banks stronger by requiring higher levels of sounder quality capital, a higher level of depositors' protection, more transparent market structures and practices, better supervision, etc. ${ }^{65}$

For example, in June 2017, for the first time since it was set up at the start of 2015, the SRB enacted a 'resolution scheme', forcing the Spanish Banco Popular to sell itself to Banco Santander for just $€ 1 .{ }^{66}$ By

\footnotetext{
59 BRRD (n 8).

60 'Bankruptcy offers an individual or business a chance to start fresh by forgiving debts that simply cannot be paid, while offering creditors a chance to obtain some measure of repayment based on the individual's or business' assets available for liquidation. In theory, the ability to file for bankruptcy can benefit an overall economy by giving persons and businesses a second chance to gain access to consumer credit and by providing creditors with a measure of debt repayment. Upon the successful completion of bankruptcy proceedings, the debtor is relieved of the debt obligations incurred prior to filing for bankruptcy.' See also 'Bankruptcy' Investopedia <http://www.investopedia.com/terms/b/bankruptcy. asp\#ixzz4e5aeZA16> accessed 15 April 2017.

61 Bankruptcy (n 60).

62 World Bank Group, Understanding Bank Recovery and Resolution in the EU: A Guidebook to the BRRD (FinSac, 2016) <http://pubdocs.worldbank.org/en/609571482207234996/ FinSAC-BRRD-Guidebook.pdf>accessed 10 April 2017.

63 'Insolvency Proceedings refer to any case, action or proceeding before a court relating to bankruptcy, reorganization, insolvency, liquidation, receivership, dissolution, windingup or relief of debtors, or any general assignment for the benefit of creditors, composition, marshalling of assets for creditors, or other similar arrangement in respect of its creditors generally or any substantial portion of its creditors.' See 'Insolvency' Investopedia <http:// www.investopedia.com/terms/i/insolvency.asp> accessed 15 April 2017; Council Regulation (EC) 1346/2000 of 29 May 2000 on insolvency proceedings [2000] OJ L160.

64 BRRD (nn 8 and 59) art 45.

65 ibid, art 38.

66 Fiona Maxwell 'Europe’s Banking Rules Show Teeth' (Politico, 7 June 2017)

<http:/ / www.politico.eu/article/europes-banking-rules-show-teeth/ > accessed 27 July 2017.
} 
engineering things so that Spain's largest bank took over its sixth largest, EU regulators allowed the ailing Banco Popular operation to continue under normal business conditions while preventing a messy financial meltdown. ${ }^{67}$ As envisaged in the Single Rulebook, the bank's investors suffered financial consequences, but, on the other side, a taxpayer bailout and the risk of sovereign default were avoided. ${ }^{68}$

\subsection{The single resolution board and its powers}

To put it simply, the Board is the central part and the main resolution authority within the EBU. Together with the National Resolution Authorities (hereinafter: NRA) of the MSs, it forms the Single Resolution Mechanism (SRM), and works closely on the resolution process with the Commission, the European Parliament, the ECB and National Competent Authorities (hereinafter: NCA). ${ }^{69}$ As Elke König, Chair of the SRB, said 'The SRB was created as a mean through which bailouts and failing, the worst-case scenario, of financial institutions in the Eurozone will be avoided'. ${ }^{70}$ The SRB is set up as an EU agency, with headquarters in Brussels, and legal personality. ${ }^{71}$ It is comprised of a Chair, where four full-time executive members sit plus a member of the NRA that were setup in the Eurozone MSs, all 19 of them. ${ }^{72}$ The representatives of the ECB and the European Commission have permanent observer status in plenary and executive sessions. ${ }^{73}$ The SRB is financed by the private sector and its budget is not part of the EU budget, so its funding and resolution activities should not inflict budgetary liability on the MSs. ${ }^{74} \mathrm{~A}$ wide range of financial institutions fall directly under its responsibility, namely all cross-border and significant banks, those that have assets exceeding $€ 30$ billion, whilst the NRA of the MS supervises other less significant institutions in the country. ${ }^{75}$

\footnotetext{
67 ibid.

68 ibid.

69 Nikolaos Papanikolaou, 'The Road Towards the Establishment of the European Banking Union' (2015) MPRA Paper 62463 <https://mpra.ub.uni-muenchen.de/id/eprint/62463> accessed 10 April 2017.

70 Single Resolution Board <https://srb.europa.eu/> accessed 10 April 2017.

71 SRM Regulation (n 13) art 7(5).

72 ibid, art 43.

73 ibid, art 43(3).

74 SRM Regulation (n 13) art 57(2). It is, however, possible that some activities within the resolution procedure depend on financing from the EU budget. Such situations have been recognised in the SRF-IGA provisions where the Eurozone MSs agree to reimburse the MS outside the Eurozone and supervision for their share of the EU budget used to meet liabilities and costs in relation to tasks stipulated in the SRMR; SRM Regulation Recital 99; SRF-IGA Recital 21, art 15.

75 ibid, art 15.
} 
The SRB is vested with various powers designed to complement the separate roles that it plays as a single Union resolution authority. Starting with the broadest one, the SRB is 'responsible for the effective and consistent functioning of the SRM' ${ }^{76}$ Still, it is bound to exercise its tasks 'in close cooperation with national resolution authorities'. ${ }^{77}$

The powers given to SRB in order to ensure the effective functioning of the EU economy include several categories:

- the SRB issues guidelines and general instructions to national resolution authorities according to which the tasks are performed and resolution decisions are adopted;

- investigatory powers, including on-site inspections;

- supervisory powers as regards the execution of the resolution scheme by the national resolution authorities, and supervisory powers at the SRB's own request over the performance of the tasks initially entrusted to the national resolution authorities;

- the SRB receives from national resolution authorities draft decisions on which it may express its views; and

- sanctioning powers in certain cases. ${ }^{78}$

Since the Board is the focal point of the EBU, it has at its disposal a wide range of powers. Because the Board is 'only' an EU agency, this makes its establishment significant, high profile and controversial. ${ }^{79}$ The SRB's powers enable the EU to have an effective single venue in dealing with potential bank failures and banking and financial crisis. However, it should be stressed that the establishment of such a powerful EU agency and the transfer of such implementing powers from the national level to the EU level should be conducted in accordance with the current constitutional framework as envisaged by the ratified Treaty of Lisbon.

In the course of examining various powers of the SRB, the relation to the principle of institutional balance, explained in the introductory section, is worth mentioning. Do its powers in any way encroach on any of the powers of other bodies and, even more importantly, institutions,

76 Marta Božina Beroš, 'Some Reflections on the Governance and Accountability of the Single Resolution Board' (2017) TARN Working Paper Series 3/2017 <https://papers.ssrn. com/sol3/papers.cfm?abstract_id=2940198> accessed 17 April 2017.

77 ibid, 1-14.

78 Single Resolution Board, 'The Single Resolution Mechanism: Introduction to Resolution Planning' (2016)<https://srb.europa.eu/sites/srbsite/files/intro_resplanning.pdf.pdf> accessed 10 April 2017.

79 Bernhard Speyer, 'EU Banking Union - Right Idea, Poor Execution' (Deutsche Bank Research, EU Monitor, 4 September 2014) 14 <www.dbresearch.com/PROD/DBR_INTERNET_EN-PROD/PROD0000000000319670/EU+Banking+Union\%3A+Right+idea,+poor+ex ecution.PDF> accessed 17 April 2017. 
notably the European Commission as the executive arm of the Union? According to Andromachi Georgosouli, the SRB's sanctioning powers, like the one to impose a penalty on a bank that has failed to supply requested information, ${ }^{80}$ are not a cause for concern because they are 'heavily qualified and are to be activated in very limited circumstances' ${ }^{81}$

In today's world of alternative facts, reality is nothing, perception is everything, ${ }^{82}$ so it is necessary not only for the establishment of such a powerful EU agency and the transfer of such implementing powers from the national level to the EU level to be done in accordance with the current constitutional framework, but also that it is perceived in such a way by the European public.

Even though the EU has claimed it has respected the necessary legal and political requirements, it is not perceived in that way. For instance, the winding-up of Veneto Banca and Banca Popolare di Vicenza gave the EU a bad press even from pro-EU media, eg: 'the European Union authorities seem to be making up the rules on banking bailouts as they go along, yet one cannot get around the fact that the spirit of the relevant EU banking directive has been ignored. The rules apply, except when they don't, it seems'. ${ }^{83}$

Since (the at times unwarranted) poor perception of the EU is hurting its cause, it is imperative to settle the debate about the appropriateness of article 114 TFEU for the establishment of the SRB. Someone may ask how the judicial debate concerning the appropriate legal basis for the conferral of powers on the SRB affects the perception of the SRB's legitimacy. The answer is that if the scathing criticism is undeserving, without a rebuttal of such criticism, the prevailing conclusion will be that the SRB was not constructed on legitimate grounds.

\section{The Single Resolution Board and the principle of conferral: an odd couple?}

The EU is often accused of 'power grab' when it bestows powers on a current or a newly created EU agency. ${ }^{84}$ This is the consequence of the

\footnotetext{
80 SRM Regulation (n 13) arts 38(2)(a), 39(1)(a).

81 For more details on SRB's sanctioning powers, see Andromachi Georgosouli, 'Regulatory Incentive Realignment and the EU Legal Framework of Bank Resolution' (2016) 10(2) Brooklyn Journal of Corporate, Financial \& Commercial Law <http://brooklynworks.brooklaw. edu/cgi/viewcontent.cgi?article=1216\&context=bjcfcl $>$ accessed 25 April 2017 .

82 Terry Goodkind, Sword of Truth: Wizard's First Rule (vol 1, TOR 1997) 357.

83 Nils Pratley, 'Italy's $€ 17$ bn Bank Job: Self-Preservation at a Long-Term EU Price?' The Guardian (London, 26 June 2017)<https://www.theguardian.com/business/2017/ jun/26/italy-bank-eu-rescue-veneto-banca-banca-popolare-di-vicenza> accessed 7 August 2017.

84 Lana Clements, 'EU Power Grab: Brussels Tries to Take Control of Non-EU Banks through
} 
constitutional structure of the EU, which is based on the conferral of powers by the MSs to the EU level. The principle of conferral is that the EU is a Union of MSs, and all its competences are voluntarily conferred on it by its MSs. ${ }^{85}$ Therefore, the creation of a new agency has to fit within the enumeration of powers in the Treaties.

To put it simply, the EU can bestow powers on an EU agency, ie create a new EU agency by two methods. The first method is via a 'specific' legal basis for the particular policy pursued. ${ }^{86}$ The institutions agreed that the legal instrument that establishes an individual regulatory agency has to have for its legal basis an article of the Treaty which constitutes the specific legal basis for the particular policy pursued. ${ }^{87}$ For the Board, that 'specific' legal basis was article 114 TFEU which requires the European Parliament and the Council to adopt the measures in accordance with the ordinary legislative procedure. ${ }^{88}$

The second method is via a 'residual' legal basis, meaning it can be used when no other Treaty article allows Community competence to be exercised. ${ }^{89}$ That 'residual' legal basis is article 352 TFEU $^{90}$ which requires the Council to reach the decision unanimously on a proposal from the Commission and after obtaining the consent of the European Parliament (see more on the appropriateness of using article 352 TFEU instead of article 114 TFEU in subsection 3.2).

Whereas Article 352 TFEU demands unanimity in the Council and therefore gives each MS a power of veto, the procedure of article 114 TFEU is governed by the ordinary legislative procedure, and an individual

Reforms' Express (London 24 November 2016) <www.express.co.uk/finance/city/736059/ EU-POWER-GRAB-Brussels-non-EU-banks-reforms> accessed 15 April 2017.

85 Conferral (n 29).

86 Commission, 'Draft of Interinstitutional agreement on the operating framework for the European regulatory agencies' COM (2005) 59 final, 13.

87 ibid, art 16.

88 Although there are a lot of stages and exceptions to the ordinary legislative procedure, it is basically a co-decision process of adopting a new legislation in five steps. The European Commission submits a proposal to the Council and the European Parliament. The Council and the Parliament adopt a legislative proposal either at the first reading or at the second reading. If the two institutions do not reach an agreement after the second reading, a conciliation committee is convened. If the text agreed by the conciliation committee is acceptable to both institutions at the third reading, the legislative act is adopted. If a legislative proposal is rejected at any stage of the procedure, or if the Parliament and Council cannot reach a compromise, the proposal is not adopted and the procedure ends. See, European Parliament, Legislative powers, Ordinary legislative procedure <http: / www.europarl.europa.eu/aboutparliament/en/20150201PVL00004/Legislative-powers> accessed 27 March 2017.

89 Commission, 'Proposal for a Framework Regulation for Macro-Financial Assistance' SEC (2011) 865 final.

90 TFEU, art 352 (ex Article 308 TEC) (2008) 115 Official Journal 0196. 
MS can be outvoted which consequently means that they have less sovereignty and less control over the decision-making. Does that mean that the procedure of article 114 TFEU is contrary to the fundamental EU law principle of conferral? No, because each MS voluntarily gave up a bit of its sovereignty when ratifying the Treaty of Lisbon, thereby giving its consent to the usage of article 114 TFEU and the possibility of being outvoted in favour of the greater good - the internal market of the EU. However, MSs did not give carte blanche to the EU in deciding when unanimous consent of the Council is needed and when it is not. MSs gave up a bit of their sovereignty and gave their consent to the use of article 114 TFEU and the possibility of being outvoted only under the prescribed conditions of article 114 TFEU. The exact wording of article 114(1) TFEU is:

1. Save where otherwise provided in the Treaties, the following provisions shall apply for the achievement of the objectives set out in Article 26. The European Parliament and the Council shall, acting in accordance with the ordinary legislative procedure and after consulting the Economic and Social Committee, adopt the measures for the approximation of the provisions laid down by law, regulation or administrative action in Member States which have as their object the establishment and functioning of the internal market. ${ }^{91}$

Since this paper delves into the problem of bestowing powers on EU agencies and the potential of an infraction of the principle of conferral, in order to ensure a better understanding, subsection 3.1, will briefly present EU agencies in general and examine the institutional and interinstitutional acts surrounding the factual development of EU agencies. Then, the section will examine the aforementioned first main question of the paper: "Was article 114 TFEU a valid legal basis for the adoption of the SRM Regulation by which the EU agency "Single Resolution Board" was established?'

The case law (eg Tobacco Advertising and ESMA) ${ }^{92}$ explained that two cumulative conditions have to be fulfilled for the use of Article 114 TFEU as a valid legal basis for a measure, including for the creation of an agency. Therefore, it is crucial to contemplate whether these two conditions were fulfilled. The conditions are the following: ${ }^{93}$

- a measure has to be adopted for the approximation of the provisions laid down by law, regulation or administrative action (hereinafter: approximation of the provisions); and

\footnotetext{
91 Art 114 TFEU (ex article 95 TEC) (2008) 115 OJ C94.

92 ESMA (n 34) para 100; Case C-376/98 Federal Republic of Germany v European Parliament and Council of the European Union ECLI:EU:C:2000:544, paras 75-105.

93 ESMA (n 34) para 100.
} 
- its object has to be the establishment and functioning of the internal market.

Therefore, subsection 3.2, will first scrutinise whether the first condition of article 114 TFEU has been met. More precisely, it will examine whether a centralisation of a resolution mechanism leads to the approximation of the provisions and whether the setting up of an EU agency with centralised implementing powers leads to the approximation of the provisions.

After this, subsection 3.3 will evaluate whether the second condition of article 114 TFEU has been met. More precisely, it will examine whether the object of centralisation of a resolution mechanism is the establishment and the functioning of the internal market and whether the object of setting up an EU agency with centralised implementing powers is the establishment and the functioning of the internal market.

If both conditions of article 114 TFEU are cumulatively fulfilled, the decision to establish the Board (which was taken through the ordinary legislative procedure) is valid and in accordance with the Treaty of Lisbon. On the other hand, if the two conditions of article 114 TFEU are not cumulatively fulfilled, the decision to establish the Board was reached on an invalid legal basis and should have been reached in the Council by a unanimous decision and on the legal basis of article 352 TFEU. If that is the case, then the answer to the first main question is negative; article 114 TFEU was not a valid legal basis for the adoption of the SRM Regulation by which the Board was established. Moreover, it would mean that the Board was not established in accordance with the constitutional framework of the EU.

By the creation of agencies with implementing and enforcement powers at the EU level, the decisions enacted at the European level cease to be dependent on the MS bodies, thus modifying the EU federal level into a self-sufficient legal order.

It should be considered that any transition from a system of EU vertical federalism to a system of EU horizontal federalism is built on sand if it is based on an infraction of the principle of conferral, a fundamental EU law principle.

As many (in academia and, eg, Wolfgang Schäuble) ${ }^{94}$ have claimed that article 114 TFEU was not an appropriate legal basis, and that the SRM Regulation could only have been adopted on the basis of article 352 TFEU, it should be considered whether article 114 TFEU was, in fact, the appropriate legal basis.

94 Engelen (n 35); Hofmann and Morini (n 45) 419. 
Another line of thinking might be whether the judicial interpretation of the reach of article 114 TFEU is sufficient, in the first place, to justify the SRB's powers in order to say that the SRB was built on a rock. As the interpretation of article 114 TFEU has been criticised as being too broad, one might ask if this judicial test is sufficient to understand whether the SRB exercises legitimate powers. ${ }^{95}$ Although this is an interesting line of thinking, the paper will not go into further analysis, because such a question is less about whether the establishment of the SRB was in accordance with current EU constitutional framework than about the Court's previous and current interpretation of the constitutional framework in general, regardless of the SRB, which would unfortunately exceed the scope of this paper.

\subsection{General overview of EU agencies}

Agencies appeared for the first time on the EU institutional landscape in 1975, a greater number of them were established in the $1990 \mathrm{~s},{ }^{96}$ and 2016 finished with more than 30 of them. ${ }^{97}$ Although each individual agency has its specific raison d'être, generally speaking, the need for the creation of agencies can be broadly linked to the development of a system of integrated administration in Europe. ${ }^{98}$ With the 'grand' EU institutions more or less susceptible to the interests of the various MSs and politics, the establishment of more 'technical' agencies to offer support from the stage of decision-making up to the implementation of Community policies was not opposed by institutions or MSs per se. Rather, they started to be questioned once it was realised that with the pace of their establishment and ever-wider competences they were taking up unmistakable space on the EU's institutional landscape, but without a stronghold in its Treaty or in any of its acts, for that matter. As will be seen, despite the numerous interinstitutional documents dealing with this matter, the problem of the legal basis and the scope of powers, both from the perspective of the MSs and academia, became once again visible with the setting up of the SRB.

\footnotetext{
95 See more in S Weatherill, 'The Limits of Legislative Harmonization Ten Years after Tobacco Advertising: How the Court's Case Law Has Become a Drafting Guide' (2011) 12 German L J 827.

96 Commission, 'The operating framework for the European Regulatory Agencies' (Communication) COM (2002) 718 final.

97 A list of decentralised EU agencies which help to implement policies and to make decisions is available at <https://europa.eu/european-union/about-eu/agencies/decentralised-agencies_en> accessed 26 March 2017.

98 For a more in-depth introduction to the notion of the functional, organisational and procedural point of view of EU administration, see Herwig $\mathrm{CH}$ Hofmann, Gerard Rowe and Alexander Türk (eds), Administrative Law and Policy of the EU (OUP 2011) 3. For an analysis of the notion of networks of administrations, see eg Wolfgang Weiss, Der Europäische Verwaltungsverbund, (Duncker \& Humblot 2010) 85.
} 
To start from the basics, agencies as distinctive bodies were not mentioned in the Founding Treaties until the Treaty of Lisbon, and even there they appear in most cases just in the sequence comprising institutions, bodies, offices and agencies' related to the jurisdiction of the Court of Justice over the acts of such bodies. Any definition or description of what is an EU agency was not included.

In the early 2000s, the White Paper on European Governance envisaged agencies as a means to the better application of EU rules, ${ }^{99}$ while the Commission's Communication on 'Better Law-making' saw them as the Commission's partners in an executive function. ${ }^{100}$ Their usefulness to 'facilitate the use of experts outside the normal bureaucratic structure (...) and insulate technical regulatory issues from political change'101 was evident, but what was lacking were more coherent and transparent provisions for their operation and supervision. Governed by that aim, in the Commission's Communication 'The operating framework for the European Regulatory Agencies', two main types of agencies were identified - executive and regulatory ones, with two subtypes of the latter, decisionmaking and regulatory agencies. ${ }^{102}$

Conditions for creating and governing executive agencies which are always set up for a limited period of time are found in Council Regulation No 58/2003, which entrusts them with managerial tasks and subjects them to strict supervision by the Commission. ${ }^{103}$ Due to the narrower scope of their tasks, lesser independence, and a clearer position in the Union's institutional framework, there are fewer encompassing legal problems.

On the other hand, regulatory agencies are set up indefinitely to be actively involved in the executive in order to regulate a specific sector at the Community level rather than at the MS level. ${ }^{104}$ Decision-making agencies are empowered to 'enact instruments binding on third parties', but mostly in the area where the predominant public interest is clear and where there is no need to exercise political judgment. ${ }^{105}$ Regulatory agencies do not have real decision-making powers, but rather assist the

\footnotetext{
99 Commission, 'White Paper on Governance' COM (2001) 428 final.

100 Commission, 'European Governance: Better law-making' COM (2002) 275 final.

${ }^{101}$ Paul Craig and Gráinne de Búrca, EU Law: Text, Cases and Materials (6th edn, OUP 2015) 69.

102 Commission, 'The operating framework for the European Regulatory Agencies' (Communication) COM (2002) 718 final.

${ }^{103}$ Council Regulation (EC) No 58/2003 of 19 December 2002 laying down the statute for executive agencies to be entrusted with certain tasks in the management of Community programmes OJ L11/1.

${ }^{104}$ Commission (n 89) art 4.

105 Craig and Búrca (n 101).
} 
Commission with organisation and coordination in performing executive tasks in the area where high technical specialisation is needed. ${ }^{106}$

From these few first documents, it can be inferred that the SRB would fall into the second category as a regulatory agency, and more precisely as a decision-making agency. On the other hand, the constraint of the 'clear and predominant public interest and the absence of political judgment' as one of the main characteristics of the group is hardly imaginable in the case of the SRB, given the highly sensitive area it operates in.

\subsubsection{The Commission's draft interinstitutional agreement on the operating framework for European Regulatory Agencies}

The Commission's Draft Interinstitutional Agreement on the operating framework for European regulatory agencies, ${ }^{107}$ submitted to the Council and Parliament in 2005, followed (though not always) ${ }^{108}$ in more detail on the broad principles laid down in the Communication meant to govern the creation, the functioning, the powers accorded to the agencies, their internal structure, the financial and budgetary aspects, as well as the controls to be conducted over them.

The most important issue was clarification of the position agencies were taking in the Union's institutional landscape and the issue of, first, the possibility of conferral of powers to the agencies, and, second, the scope of that conferral. The range of powers which may be accorded to EU agencies is important from the perspective of both the EU institutions and the MSs, because of the principle of institutional balance for the former and the principle of conferral of powers for the latter.

As mentioned above, the institutions agreed that the legal instrument that establishes an individual regulatory agency has to have for its legal basis an article of the Treaty which constitutes the specific legal basis for the particular policy pursued, as opposed to the practice until that point to use article 352 TFEU (ex 308 EC). ${ }^{109}$ This article retained its role as a 'residual' legal basis, meaning it can be used when no other Treaty article allows Community competence to be exercised. ${ }^{110}$

\footnotetext{
106 Commission (n 96).

107 Commission, 'Draft Interinstitutional agreement on the operating framework for the European regulatory agencies' COM (2005) 59 final.

108 Compare, for example, the envisaged appointment of the 'Director of the Board of the agency in the operating framework for the European Regulatory Agencies' COM (2002) 718 final, arts 8-10 and in the 'Draft Interinstitutional Agreement on the operating framework for the European regulatory agencies' COM (2005) 59 final 16.

109 Commission (n 107) para 13.

110 ibid, para 14.
} 
On the notion of conferral of powers, the Commission's Draft indicates the constraints of the institutional system and the case law of the Court of Justice', referring to the Meroni and Romano judgments. ${ }^{111}$ In accordance with the mentioned judgments, the Commission stated that the agencies may not:

- adopt general regulatory measures;

- have decision-making powers conferred on them in areas in which they would be required to arbitrate in conflicts between public interests or exercise political discretion;

- have responsibilities entrusted to them with respect to which the EC Treaty has conferred direct decision-making powers on the Commission. ${ }^{112}$

Additionally, it stated that '(a)ny powers delegated by the legislative authority must be strictly defined and subject to rigorous controls'. ${ }^{113}$

Reference was made to the Meroni judgment due, apart from facts concerned with EU agencies, to the principle of institutional balance being derived precisely from it, requiring that 'each (...) institution has to act in accordance with the powers conferred on it by the Treaties, in accordance with the division of powers'. ${ }^{114}$ It was important, not just for reasons of the political accountability of the body, because one may point out that the European parliament is the only democratically elected EU institution, but also for the checks and balances between institutions and the architecture of their powers as laid down in the Treaties to which the MSs had agreed, to create space for the agencies, but by not taking anyone else's. Additionally, the existence and role of EU bodies as yet another example of 'communitarisation' within the EU but without a solid ground in the Treaty - only this time not in the legislative sense but in the executive sense of trading vertical federalism for horizontal federalism had to be addressed in a way that would not upset MSs.

According to Merijn Chamon, the limits the Commission was seeking to impose had already been exceeded by the powers granted to the existing agencies. Chamon concluded that the 'Commission's proposal

\footnotetext{
${ }_{111}$ Commission (n 107) para 5; see more in Case C 9/56 Meroni \& Co, Industrie Metallurgiche, SpA v High Authority of the European Coal and Steel Community (Meroni) ECLI:EU:C:1958:7; Case C 98/80 Giuseppe Romano $v$ Institut national d'assurance maladie-invalidit (Romano) ECLI:EU:C:1981:104.

112 Commission (n 107) paras 11-2.

113 Commission (n 107) para 12.

${ }^{114}$ EUR-Lex, Glossary of Summaries <http://eur-lex.europa.eu/summary/glossary/institutional_balance.html> accessed 16 October 2017.
} 
consists for a large part in codifying existing agency practice but fails to address certain fundamental issues'. ${ }^{115}$

It seems that the Commission more often expresses in its documents the need for a meaningful framework governing the delegation of powers to the agencies with an accompanying vague referral to, mostly, the Meroni doctrine ${ }^{116}$ than it manages to extract from it clear, precise and transparent conditions. One has to agree with Chamon that it seems that the factual evolution of the agencies is always one step ahead of the institutions that are trying to keep pace with the interpretation of the Treaties as they look at a given moment.

The discussion with the Parliament and the Council on the draft interinstitutional agreement ended fruitlessly, though not completely without the expressed will to cooperate. ${ }^{117}$ In 2008, the Commission, in the Communication 'European Agencies: The way forward', repeated the need for a 'common vision about the role and functions of regulatory agencies' but ultimately withdrew its proposed draft interinstitutional agreement. ${ }^{118}$

In the same document, the Commission announced that it would propose no new regulatory agencies until the end of $2009,{ }^{119}$ but, faced with the consequences of the financial and economic crisis of the $2008,{ }^{120}$ in the wake of the creation of the EBU, proposed the establishment of the ESMA,

\footnotetext{
${ }^{115}$ Merijn Chamon, 'EU Agencies: Does the Meroni Doctrine Make Sense?' (2010) 17(3) Maastricht Journal of European \& Comparative Law 281.

116 The so-called 'Meroni doctrine' confirms the ability of the EU Institutions to delegate powers to EU agencies, but also constrains the delegation of such powers where their use would require the exercise of wide discretion. The Court's judgment laid down three key conditions (ie three key criteria) of the 'Meroni doctrine': First condition: an Institution may not delegate powers that it does not itself possess; Second condition: delegation of powers, which 'involves clearly defined executive powers [...] which can be subject to strict review in light of objective criteria, determined by the delegating authority', is permissible; Third condition: delegation of powers which 'involves a discretionary power, implying a wide margin of discretion, which may [...] make possible the execution of actual economic policy' is impermissible. This is because the power 'replaces the choices of the delegator by the choices of the delegate' and thereby 'brings about an actual transfer of responsibility'. Meroni (n 111) para 152; for example, the Commission states that ' (...) this power will be limited (...) in accordance with the institutional system and the case law of the Court of Justice', referring in the footnote to the Meroni case.

117 See also European Parliament Resolution on the Draft interinstitutional agreement presented by the Commission on the operating framework for the European regulatory agencies (2006) OJ C285/123 and the Answer of Lord Bach (President-in-Office of the Council) to oral question 0-0093/2005 by Jo Leinen and Janusz Lewandowski, on behalf of the AFCO Committee, to the Council on the 'Draft interinstitutional agreement on the operating framework for the European regulatory agencies'.

${ }^{118}$ Commission, 'Communication to the European Parliament and the Council - European Agencies - The way forward' COM (2008) 135 final, formally done in Withdrawal of obsolete Commission proposals (2009) OJ C71/17.

119 Commission, European agencies (n 118) 9.

120 Chamon (n 115) 45.
} 
the European Banking Authority (hereinafter: EBA) and the European Insurance and Occupational Pensions Authority (hereinafter: EIOPA). ${ }^{121}$

In addition, one more body has emerged from the Commission's 2008 Communication, an Inter-Institutional Working Group (IIWG) whose role was to address 'a number of key issues' regarding agencies, and its work, in turn, resulted in the 'Joint Statement of the European Parliament, the Council of the EU and the European Commission on decentralised agencies' of 2012. ${ }^{122}$ It was, finally, 'the first political agreement on EU decentralised agencies of its kind' which would serve as a 'political blueprint guiding future horizontal initiatives and reforms of individual EU agencies. ${ }^{123}$ The document that was labelled as flesh on the bones of the Joint Statement was the Commission's 'Roadmap on the follow-up to the Common Approach on EU decentralised agencies' adopted at the end of 2012. ${ }^{124}$ The Commission gave as its main objective for the implementation of the Common Approach 'more balanced governance, improved efficiency and accountability and greater coherence'. ${ }^{125}$ It provided more detailed, technical guidelines for the establishment and functioning of agencies, ${ }^{126}$ including articulate criteria for assessing their work. This time, it was clear that agencies were there to stay.

After this quick general description of the process of 'agencification' at the EU level, we should now turn to the issue of the appropriateness of article 114 TFEU for the establishment of the SRB.

\footnotetext{
${ }^{121}$ Commission, 'Proposal for a Regulation of the European Parliament and of the Council establishing a European Banking Authority' COM (2009) 501 final; Commission, 'Proposal for a Regulation of the European Parliament and of the Council establishing a European Insurance and Occupational Pensions Authority' COM (2009) 502 final.

122 European Parliament, Council of the EU, European Commission, 'Joint Statement on decentralised agencies' (2012) <https:/ / europa.eu/european-union/sites/europaeu/files/ docs/body/joint_statement_and_common_approach_2012_en.pdf> accessed 29 August 2017.

${ }^{123}$ Commission, 'Roadmap on the Follow- Up to the Common Approach on EU decentralised Agencies COM (2014) 86 final <https://europa.eu/european-union/sites/europaeu/files/ docs/body/2012-12-18_roadmap_on_the_follow_up_to_the_common_approach_on_eu_decentralised_agencies_en.pdf> accessed 27 August 2017.

${ }^{124}$ Commission, 'Roadmap on the Follow-Up to the Common Approach on EU decentralised Agencies (press release) (2014) <http://europa.eu/rapid/press-release_IP-12-1396_ en.htm> accessed 20 August 2017.

125 Commission (n 123).

126 The usefulness of the setting up of the SRB was explicitly mentioned in a report by the Commission. Commission, 'Progress report on the implementation of the Common Approach' (2015) <http://ec.europa.eu/transparency/regdoc/rep/1/2015/EN/1-2015-179EN-F1-1.PDF> accessed 27 August 2017.
} 


\subsection{The first condition of article 114(1) TFEU - approximation of the provisions laid down by law, regulation or administrative action}

The first condition of article 114(1) TFEU states that the measure in question has to be 'adopted for the approximation of the provisions laid down by law, regulation or administrative action'. ${ }^{127}$ In order to conclude what such a requirement means for the establishment of an agency, it is necessary to consider the case law of the Court concerning the first condition of article 114(1) TFEU in order to analyse:

- whether centralisation of a resolution mechanism leads to the approximation of the provisions; and

- whether the setting up of an EU agency (ie the SRB) with centralised implementing powers leads to the approximation of the provisions.

As regards the centralisation of a resolution mechanism, it is important to emphasise that the BRRD sets only the minimum harmonisation rules relating to the resolution of banks within the EBU, and thus does not completely avoid the risk of taking divergent, national-incentive driven decisions of the NRAs. ${ }^{128}$ Therefore, uniform provisions of the SRM as a regulation, which are consistent with those in the BRRD, ${ }^{129}$ ensure a level playing field within financial markets but only through the centralised application of the resolution rules by a single Union authority, ie the SRB. ${ }^{130}$ Hence, it can be concluded that the centralisation of a resolution mechanism leads to the approximation of the provisions.

Moreover, a conclusion should be reached that the setting up of an EU agency (ie the SRB) with centralised implementing powers leads to the approximation of the provisions because it avoids the risk of taking divergent, national-incentive driven decisions of the NRAs.

It is useful to have one central agency at the EU level that is in charge of resolution, rather than multiple NRAs for the sake of the effective and uniform application of law. Such an EU agency with centralised implementing powers is an effective tool to combat omnipresent banking sector issues and crises. On the other hand, NRAs are not marginalised, but retain their relevance as SRB informers, partners in preparing resolution schemes and executors of its resolution decisions. ${ }^{131}$ However,

\footnotetext{
127 TFEU (n 15) art 114(1).

128 SRM Regulation (n 13) Recital 10.

129 ibid, Recital 18.

130 ibid, Recitals 16, 21.

${ }^{131}$ Single Resolution Board, 'Decision of the plenary session of the Board of 28 June 2016
} 
even though such an EU agency with centralised implementing powers is an effective tool, still all the other legal requirements must be fulfilled because the EU cannot go with the Machiavellian logic that 'the end justifies the means'. ${ }^{132}$

When discussing the setting up of an EU agency with centralised implementing powers, it is important to mention the landmark case Smoke Flavourings. ${ }^{133}$ In it, the Court rejected the idea that the expression 'measure for the approximation' from article 114 TFEU always means a measure that itself harmonises national laws, in a way that, for example, regulations do, or that it requires simultaneous enactment of identical legislation in each MS. ${ }^{134}$ Rather, the judgment clarifies that 'the authors of the Treaty intended to confer on the Community legislature a discretion (...) as regards the harmonization technique most appropriate for achieving the desired result, in particular in fields which are characterized by complex technical features. ${ }^{135}$ In the same judgment, the Court asked that where the harmonisation process is comprised within several stages, the Union legislator has to determine in the basic legislative act all the essential elements of the measure in question and only consequently a mechanism for implementing those elements. ${ }^{136}$

Further development as regard the scope of the expression 'a measure for approximation' occurred in the ENISA case, where the Court explicitly stated that ' $(\mathrm{t})$ he legislature may deem it necessary to provide for the establishment of a Community body responsible for contributing to the implementation of a process of harmonization'. ${ }^{137}$

In the ESMA case, it was added that an EU body as a measure contributing to the sought harmonisation was particularly justified when 'the measures to be adopted are dependent on specific professional and technical expertise and the ability of such a body to respond swiftly and appropriately'. ${ }^{138}$

The ESMA case will be mentioned throughout the paper due to the similarity of issues surrounding the ESMA and the SRB, both EU agencies established on the basis of article 114 TFEU. The ESMA case was an

establishing the framework for the practical arrangements for the cooperation within the Single Resolution Mechanism between the Single Resolution Board and national resolution authorities' PS (2016) <https://srb.europa.eu/sites/srbsite/files/srb_ps_2016_07.pdf> accessed 29 March 2017.

132 Nicolò Machiavelli, The Prince (first published 1532, Bantam Dell 1996) 122.

${ }^{133}$ Case C 66/04 United Kingdom of Great Britain and Northern Ireland $v$ European Parliament and Council of the European Union (Smoke Flavourings) ECLI:EU:C:2005:743.

134 ibid, paras 20, 28.

135 ibid, para 45.

136 ibid, paras 47 - 49.

137 ENISA (n 26).

138 ESMA (n 37) para 105. 
indicator of the Court's direction towards the EU agencies. Therefore, a brief explanation of the case is needed.

The Short Selling Regulation was adopted on the basis of article 114 TFEU. ${ }^{139}$ Article 28 of the regulation vests the ESMA with certain powers of intervention. ${ }^{140}$ Accordingly, ESMA may adopt measures that are legally binding on the EU Member States' financial markets where there is a threat to the orderly functioning and integrity of financial markets or to the stability of the whole or part of the financial system in the EU. ${ }^{141}$

As already mentioned, the UK brought an action before the Court of Justice seeking the annulment of article 28 of the Regulation. ${ }^{142}$ The UK submitted that article 114 TFEU was not the correct legal basis for the adoption of the rules laid down in article 28 of the Regulation. ${ }^{143}$ The UK also contended that ESMA had been given a very large measure of discretion of a political nature which was at odds with EU principles relating to the delegation of powers. ${ }^{144}$

In his Opinion, AG Niilo Jääskinen emphasises that whilst in principle there can be no objection to using article 114 TFEU as a legal basis for EU agencies which adopt legally binding decisions, the determining factor is whether the decisions of the agency in question either contribute to or amount to internal market harmonisation. ${ }^{145}$ In his view, the powers vested in ESMA under article 28 of the Regulation go beyond these limits; the AG points out that ESMA is uniquely empowered to make legally binding decisions in substitution of those of a competent national authority, which may well disagree with the decision of ESMA. ${ }^{146}$ This decision will prevail over any previous measure taken by the national authority. ${ }^{147}$ In the AG's view, the effect of this is to create an EU level emergency decision-making mechanism that becomes operable when the national authorities do not agree on a course of action. ${ }^{148}$ Hence, the outcome is not harmonisation but the replacement of national decision-making with EU level decision-making, which goes beyond the limits of article $114 .{ }^{149}$

After having rejected article $114 \mathrm{TFEU}$ as an appropriate legal basis, the AG suggested the use of article 352 TFEU to grant the ESMA contested

\footnotetext{
139 Regulation (EU) No 236/2012 (n 38).

140 ibid.

141 ESMA (n 37).

142 ibid.

143 ibid, paras 88-90.

144 ibid, paras 28-34.

145 Opinion of AG Jääskinen (n 40).

146 ibid, para 57.

147 ibid, para 59.

148 ibid, para 51.

149 ibid, para 52.
} 
powers since the contested powers were still necessary to prevent the internal market in financial services from being distorted. ${ }^{150}$ The AG added to this that article 352 TFEU would have enhanced democratic input, given the unanimity requirement in the Council. ${ }^{151}$

The Court ruled to the contrary, dismissing the UK's and the AG's arguments by claiming that article 28 of the Regulation was in fact directed, in keeping with the spirit of article 114 TFEU, at the harmonisation of the Member States' laws, regulations and administrative provisions relating to the supervision of a number of stocks, and the monitoring, in specific situations, of certain commercial transactions concerning those stocks. ${ }^{152}$ Similarly, the Court states that the purpose of the powers provided for in article 28 of the Regulation is to improve, in accordance with article 114 TFEU, conditions for the establishment and functioning of the internal market in the financial field. ${ }^{153}$ Accordingly, the Court found that article 114 TFEU constitutes an appropriate legal basis for the adoption of article 28 of the Regulation. ${ }^{154}$

Another judgment worth mentioning is the Vodafone case. ${ }^{155}$ It was the first judgment, concerning a type of measure a body can take, to still be considered within the boundaries of article 114 TFEU. ${ }^{156}$ It was stated there that measures for harmonisation can be directly addressed to market operators, since previous measures directed towards the MSs proved to be inefficient. ${ }^{157}$ Moreover, the Court stressed in ENISA that "nothing in the wording of Article 95 EC [now 114 TFEU] implies that the addressees of the measures (...) can only be the individual MSs'. ${ }^{158}$ Furthermore, in the General Product Safety judgment it was ascertained that laying down measures relating to a specific product or class of products is allowed, as is laying down individual measures concerning those products. ${ }^{159}$

What solidifies the SRB's position is the fact that the provisions of the BRRD and the SRM are material law - essential elements of the measure laid down in the basic legislative act and are implemented through the mechanism of the SRB, being together two inherent and

\footnotetext{
$\overline{150}$ ibid, para 54. See Chamon (n 115) 47.

151 ibid, para 58.

152 ESMA (n 37) para 112.

153 ibid, para 113.

154 ibid, para 114.

155 Case C 58/08 The Queen, on the application of Vodafone Ltd and Others $v$ Secretary of State for Business, Enterprise and Regulatory Reform (Vodafone) ECLI:EU:C:2010:321.

156 ibid.

157 ibid, para 78.

158 ENISA (n 26) para 44.

${ }^{159}$ Case C 359/92 Federal Republic of Germany $v$ Council of the European Union (General Product Safety) ECLI:EU:C:1994:306, para 37.
} 
consecutive steps of the same harmonisation effort, ${ }^{160}$ as requested in the Smoke Flavourings judgement. ${ }^{161}$ The SRB, as a Union agency, as mentioned above, is a constitutive part of the process of harmonisation, and tasks conferred on it are closely linked to the subject matter of the BRRD and the SRM which are aimed at the approximation of the national resolution rules and administrative practices. ${ }^{162}$

From the presented relevant case law, it seems that the SRB, as an EU agency with centralised implementing powers which has the power to adopt individual measures and address them to the NRAs or directly to the credit institutions, ${ }^{163}$ can be considered as a measure for approximation, therefore justifying the first condition of article 114(1) TFEU as a valid legal basis for its establishment.

In the course of the political and academic debate, fuelled mostly by the recent ESMA case, one can gain the impression that if the statement of overstepping the EU's Treaty-based competences is repeated enough times, it becomes true. Nevertheless, an analysis of the relevant case law has proven that the SRB's establishment and the choice of its legal basis can, at least for now, withstand the criticism.

\subsection{The second condition of article 114 TFEU - the establishment and the functioning of the internal market}

First, it is worth clarifying the condition 'the establishment and the functioning of the internal market'. According to the Court's Tobacco Advertising test, ${ }^{164}$ a measure should have as its objective the establishment and the functioning of the internal market. ${ }^{165}$ It is necessary to verify whether a measure adopted on the basis of article 114 TFEU 'actually contributes to the elimination of obstacles to the free movement of goods or to the free movement of services or to removing distortions of competition'. ${ }^{166}$

\footnotetext{
160 Council of the European Union, 'Opinion of the legal service' ECOFIN 787 1352413, para 36; for the detailed relationship between BRRD and the SRM Regulation (n 13), see Commission, 'Services Note: Interaction between SRM and BRRD' EUCO 104/2/13 CO EUR 9 CONCL 6 REV 2 <http://europa.eu/rapid/press-release_MEMO-14-297_en.htm> accessed 19 August 2017.

161 Smoke Flavourings (n 133) paras 47-49.

162 ENISA (n 26) para 45.

163 SRM Regulation (n 13) art 7(4)(a) for direct exercise, SRM Regulation for addressing (n 13) art 18(9).

164 Case C-376/98 Federal Republic of Germany $v$ European Parliament and Council of the European Union ECLI:EU:C:2000:544.

165 ibid, para 84. See, for more, Tamara Perišin, 'Free Movement of Goods and Limits of Regulatory Autonomy in the EU and WTO' (Asser Press 2008) 98.

166 Germany $v$ Parliament (n 159) para 95.
} 
The Court has consistently held and repeated, eg in the Smoke Flavourings judgment, that article 114(1) TFEU 'is used as a legal basis only where it is actually and objectively apparent from the legal act that its purpose is to improve the conditions of the establishment and functioning of the internal market. ${ }^{167}$ The same reasoning, albeit in more detail, was expressed in British American Tobacco and Imperial Tobacco, Swedish Match and Alliance for Natural Health cases, stating that the measure in question has to contribute to the "elimination of obstacles to the fundamental freedoms or of establishment or to the removal of distortions to competition.'168

Therefore, in order for the condition to be met, it is necessary for the measure to remove obstacles to the free movement of goods or to remove obstacles to the free movement of services or to remove distortions of competition. It is important to contextualise this case law in the case of the SRB. So, in order for the condition to be met, it is necessary for the establishment of the SRB to remove the obstacles to the free movement of banking services or to remove distortions of banking competition. More precisely, it is relevant to analyse whether the removal of obstacles to the resolution of failing banks by creating the SRB has the consequence of making the banking system in Europe safer and with fewer obstacles for the free movement of banking services.

The mere side effect of improving the conditions of the establishment and functioning of the internal market is not enough for the second condition of article 114(1) TFEU to be considered fulfilled.

It is, therefore, also necessary to answer whether the second condition of article 114 TFEU has been met. More precisely, the following will be examined:

- whether the object of centralisation of a resolution mechanism is the establishment and the functioning of the internal market; and

- whether the object of setting up an EU agency (ie the SRB) with centralised implementing powers is the establishment and the functioning of the internal market.

\footnotetext{
167 Smoke Flavourings (n 133) para 44; Case C 300/89 Commission of the European Communities $v$ Council of the European Communities ECLI:EU:C:1991:244, para 10.

168 Case C 210/03 The Queen, on the application of: Swedish Match AB and Swedish Match UK Ltd $v$ Secretary of State for Health ECLI:EU:C:2004:80, para 33; Case 154/05 The Queen, on the application of Alliance for Natural Health and Nutri-Link Ltd $v$ Secretary of State for Health (C-154/04) and The Queen, on the application of National Association of Health Stores and Health Food Manufacturers Ltd $v$ Secretary of State for Health and National Assembly for Wales (Alliance for Natural Health) ECLI:EU:C:2005:449 para 32; Case 491/01 The Queen $v$ Secretary of State for Health, ex parte British American Tobacco (Investments) Ltd and Imperial Tobacco Ltd ECLI:EU:C:2002:741 para 42.
} 


\subsubsection{Is the object of the centralisation of a resolution mechanism the establishment and the functioning of the internal market?}

As regards the centralisation of a resolution mechanism, it is important to point again to the above-mentioned ESMA judgment, in which the Court found that the contested article 28 of the Short Selling Regulation satisfies (the first and) the second condition of article 114 TFEU. ${ }^{169}$ The relevant points were that its purpose is in particular to 'ensure a high level of consumer and investor protection' for which it is necessary to 'ensure greater coordination and consistency between MSs', where the Court pointed to the cross-border implications of the sector which may threaten the 'orderly functioning and integrity of financial markets or the stability of the whole or part of the financial system in the Union'. ${ }^{170}$

The Court's reasoning on the subject was based on the text of the Recitals to the Short Selling Regulation. ${ }^{171}$ Despite the numerous pieces hailing the ESMA judgment as the saviour-of-the-day when it comes to the establishment and powers of the Union agencies, ${ }^{172}$ it is debatable how far it is recommended to use this narrow and context-specific argumentation as a precedent for other situations concerning Treaty boundaries of internal market harmonisation. ${ }^{173}$

On the other hand, a majority of academics acknowledge that centralised intervention in rules and administrative practices in the financial sectors of the MSs improves the stability of financial markets which consequently improves the conditions for the functioning of the internal market. ${ }^{174}$

Hence, one can argue that the object of the centralisation of a resolution mechanism is the establishment and the functioning of the internal market, in accordance with article 114 TFEU because the

\footnotetext{
169 ESMA (n 37) para 117.

170 ibid, paras 114-15.

171 Regulation (EU) No 236/2012 (n 38).

172 See also Pieter Van Cleynenbreugel, 'Meroni Circumvented: Article 114 TFEU and EU Regulatory Agencies' (2014) Maastricht Journal of European and Comparative Law 64; Jacques Pelkmans and Marta Simoncini, 'Mellowing Meroni: How ESMA Can Help Build the Single Market' (2014) CEPS Commentary.

173 Ferran (n 9) 80.

${ }^{174}$ Merijn Chamon made a comment for ESMA, but it applies identically for the relation SRB - banks in distress. Merijn Chamon, 'The Empowerment of Agencies under the Meroni Doctrine and Article 114 TFEU: Comment on United Kingdom v Parliament and Council (Short-selling) and the Proposed Single Resolution Mechanism' (2014) 3 European Law Review 389; Rob van Gestel, 'European Regulatory Agencies Adrift: Case C-270/12 United Kingdom of Great Britain and Northern Ireland v European Parliament and Council of the European Union, Judgment of 22 January 2014, Not Yet Reported' (2014) Maastricht Journal of European and Comparative Law 188, 192. Dissenting opinions will be discussed further in the text.
} 
banking sector also has cross-border implications which may threaten the 'orderly functioning and integrity of financial markets or the stability of the whole or part of the financial system in the Union'.

Further analysis from the economic perspective is needed to back up the claim that the object of centralisation of a resolution mechanism is the establishment and the functioning of the internal market. For this analysis from the economic perspective, Eilis Ferran offers what she calls 'reasons of substance' why article 114 TFEU as the legal basis is justifiable. ${ }^{175}$

First, simply speaking, everything is interconnected. Functioning of the single market depends on the functioning of the euro area. ${ }^{176}$ Cross-border banking groups are significant in size, so an inconsistent approach of MSs in resolution practices increases the resolution costs as well as the risk of the spill-over of the crisis and does not help to weaken the dependence of the banks on the national budgets and fragments the internal market as a whole. ${ }^{177}$ Since fragmented resolution rules and administrative practices negatively affect the MSs not participating in the Single Supervisory Mechanism (SSM) or the SRM as well, establishing an EU agency whose target is Eurozone MSs (though the rest may freely decide to participate) on the basis of article 114 TFEU is justifiable. ${ }^{178}$ After the 2008-2009 crisis, it became evident that the European Banking Union (EBU) is indispensable to ensure a more resilient internal market, ${ }^{179}$ and it was stressed throughout the process of its creation that in order to be effective, it requires both a functional SSM and SRM as its essential parts. ${ }^{180}$ Niamh Moloney suggests that the EBU's foundational regulatory technology is relatively robust, but that there are many uncertainties which attend the EBU, notably with respect to operational effectiveness, constitutional resilience, and the euro area/internal market asymmetry, and which may have far-reaching effects on EU banking market governance generally. ${ }^{181}$

\footnotetext{
175 Ferran (n 9) 80.

176 ibid, 80.

177 SRM Regulation (n 13) Recitals 9, 10, 12.

178 Regulation (n 13) Recital 12 SRM; Ferran (n 9) 80.

179 Emilios Avgouleas and Douglas W Arner, 'The Eurozone Debt Crisis and the European Banking Union: A Cautionary Tale of Failure and Reform' (2013) Edinburgh Research Explorer <http://www.research.ed.ac.uk/portal/files/14512172/Avgouleas_theeurozonedebtcrisisandtheeuropeanbanki.pdf> accessed 15 March 2017.

180 SRM Regulation (n 13) Recitals 11, 12.

${ }^{181}$ Niamh Moloney, 'European Banking Union: Assessing Its Risks and Resilience' (2014) 51 Common Market Law Review 1609, 1609.
} 
Second, financial markets are extraordinarily sensitive. ${ }^{182}$ Resolution authorities must act in a quick and decisive manner when it comes to crisis, and 'a fragmented, cross-border, multiparty, consensus-based decision-making apparatus is inefficient in that situation'. ${ }^{183}$ Hence, as stated in Recital 21 to the SRM Regulation, since the rules laid down therein can be efficiently applied only when the decision-making responsibility is centralised, the SRB is 'an element of a harmonization process that aims at improving the conditions for the functioning of the single market'. ${ }^{184}$

Third, banks based in an MS which has (or is perceived to have) lower ability to rescue ailing banks are at a competitive disadvantage. ${ }^{185}$ An unlevel playing field as regard resolution rules and practices has an impact on the banks' solvency and perceived credit risk, which in turn has a consequence on borrowing costs for the creditors, dependent on the banks' place of establishment and provision of services. ${ }^{186}$ Therefore, a situation as the one described cannot be labelled as 'a mere finding of disparities between national rules' or as the 'abstract risk of obstacles to the exercise of fundamental freedoms or of distortions of competition'. ${ }^{187}$ Thus, from the competition point of view, there is a reason to base the adoption of the SRM (and the SRB as its crucial part) on article 114 TFEU. ${ }^{188}$

Lastly, some authors argue that there is a difference between the internal market and financial stability. ${ }^{189}$ For instance, the German Minister of Finance Wolfgang Schäuble ${ }^{190}$ claims that '(A)rticle 114 aims to

\footnotetext{
182 Examples of the two opposite fun facts: Tomi Kilgore, 'Boeing's Stock Drops After Trump Tweet about Cancelling Air Force One Order' (MarketWatch, 6 December 2016) <http:// www.marketwatch.com/story/boeings-stock-drops-after-trump-tweet-to-cancel-air-forceone-order-2016-12-06> accessed 29 January 2017; Lindsey Rupp, 'Nordstrom Shares Surge After Trump's Critical Tweet' (Bloomberg, 9 February 2017) < https://www.bloomberg.com/politics / articles / 2017-02-08/nordstrom-shrugs-off-trump-s-twitter-criticism-asshares-climb> accessed 11 February 2017.

${ }^{183}$ Ferran (n 9) 81.

184 ibid, 82.

185 Commission, Explanatory Memorandum COM (2013) 530, para 3.1.

186 SRM Regulation (n 13) Recitals 3, 4.

187 Case C 376/98 Federal Republic of Germany $v$ European Parliament and Council of the European Union ECLI:EU:C:2000:544, para 84.

${ }^{188}$ Ferran (n 9) 81.

189 See Meehea Park, 'ESMA's Role as European Supervisory Authority' (Leiden Law Blog, 2 February 2014) <http://leidenlawblog.nl/articles/esmas-role-as-european-supervisoryauthority> accessed 27 January 2017.

190 The German government had several issues with the creation of the SRM and the SRF (some of them the same as the ones discussed in this paper) which were addressed in the Council's confidential legal opinions, but which were later published in the Financial Times. See, Alex Barker, 'Blow to German Banking Union Plan' Financial Times (London, 12 September 2013) <www.ft.com/content/ea7c2eb6-1b90-11e3-94a3-00144feab7de> accessed 3 February 2017; Alex Barker, 'Setback for Brussels as Lawyers warn on Banking Union Plans' Financial Times (London, 8 October 2013) <www.ft.com/content/306c4e482ffe-11e3-9eec-00144feab7de> accessed 3 February 2017.
} 
foster the proper functioning of the internal market, which encompasses all MSs in geographical terms'. ${ }^{191}$ 'Article 114 TFEU does not aim to foster the specific objective of financial stability for just part of the EU 28, namely those MSs participating in the SSM. ${ }^{192}$ The issue of the SRB covering directly only Eurozone states has already been dealt with. In addition, the legal service of the Council of the European Union in its opinion pointed to the mutual dependence of the SSM and the SRM in the process of the harmonisation of the internal market for financial services, ${ }^{193}$ and, because of that, 'the fact of being subject to the SSM can therefore be regarded as a specific attribute that places the entities falling within the scope of application of the [then] proposal in an objectively and characterized distinct position for resolution purposes'. ${ }^{194}$

As regard financial stability, one must keep in mind the ever-present interconnectedness in the sphere of financial markets and economics in general. The stability of financial markets is needed for them to function smoothly, which, consequently, through price stability and the value of the euro, affects the functioning of the internal market as well. ${ }^{195}$ Therefore, the authors reiterate their conclusion that the object of centralisation of a resolution mechanism is the establishment and the functioning of the internal market, in accordance with article 114 TFEU.

\subsubsection{Is the object of setting up an EU agency with centralised implementing powers the establishment and the functioning of the internal market?}

In this subsection, the approach of the Court in the ESMA case will be considered, ie close attention will be paid to the Recitals and the provisions of the SRM Regulation in order to analyse whether the object of setting up an EU agency with centralised implementing powers (in this case, the SRB) is the establishment and the functioning of the internal market. One has to look foremost at Recitals 2, 3, 12 and 21 to the SRM Regulation.

At the outset, the Union legislator addresses the main reason for setting up an EU agency with centralised implementing powers. It invokes market instability and the lack of confidence in the market, which occurs because of the divergences between national resolution rules, the different incentives of each MS, and the lack of a unified decision-making process in bank resolutions. ${ }^{196}$ Since these differences 'have an impact

\footnotetext{
${ }^{191}$ Schäuble (n 36).

192 ibid (n 36).

${ }^{193}$ Council of the European Union, 'Opinion of the legal service' ECOFIN 787 1352413, paras 36-39.

194 ibid, para 75.

${ }^{195}$ Ferran (n 9) 80.

196 SRM Regulation (n 13) Recitals 2, 3.
} 
on the perceived credit risk, financial soundness and solvency of their [creditors] banks', freedom of establishment and the free provision of services within the internal (financial) market are obstructed. ${ }^{197}$

Argumentum a contrario, the establishment of an EU agency with centralised implementing powers, ie the SRB, would

ensure a neutral approach in dealing with failing banks and therefore increase stability of the banks of the participating Member States and prevent the spill-over of crises into non-participating Member States and will thus facilitate the functioning of the internal market as a whole. ${ }^{198}$

Furthermore, Recital 21 expressly sets fair competition and preventing obstacles to the free exercise of fundamental freedoms as the SRB's objective, and stresses the importance of the centralised application of the resolution rules found in the BRRD and the SRM Regulation by a single Union resolution authority to 'avoid divergent interpretations across the MSs'. ${ }^{199}$

The Union legislator makes a strong case against a fragmented banking market, at the same time advocating not just the unified resolution rules but their centralised application as well. According to the Recitals, establishment of the SRB as the Union's single resolution body is indeed a measure for which it is actually and objectively apparent that its purpose is to improve the conditions of the establishment and functioning of the internal market, ie that it satisfies the second condition of article 114 TFEU.

In any case, the timeline between the requests and the reasoning of the ESMA case, reported in January 2014, and the SRM Regulation, adopted in July 2014, is rather symptomatic. When analysing the Recitals of the SRM Regulation, it easy to be convinced that the Union legislator took into account the ESMA case while enacting the SRM regulation and establishing the SRB.

It can be concluded that the object of setting up an EU agency with centralised implementing powers (ie the SRB) is the establishment and the functioning of the internal market.

\footnotetext{
197 SRM Regulation (n 13) Recital 3.

198 SRM Regulation (n 13) Recital 12.

199 SRM Regulation (n 13) Recital 21.
} 


\subsection{Article 114 TFEU is a valid legal basis for the SRB and the transition}

It appears that the development of the case law of the Court indicates the Court's readiness to allow a flexible interpretation of the scope of article 114 TFEU, and its pragmatic approach towards the factual creation of new structures within the EU which came as a response to changed economic (crisis and globalised markets) and political (enlargement of the EU overloading the institutions) circumstances. Two paragraphs taken from the Opinion of the legal service of the Council of the EU on the proposal of the SRM summarise the interplay between the law and the daily decision-making of the institutions. ${ }^{200}$

First, the Opinion of the legal service recalled the Vodafone judgment in which the Court stated that the legislator is free to complement and support a particular harmonization measure with another, based on a different conceptual approach - ie, a centralized process of decision when it considers that the first one is not sufficient to achieve the level of harmonization desired'. ${ }^{201}$ Then it stated that article 114 TFEU may be the legal basis for the establishment of the SRM as long as there is a genuine need for a uniform application of the resolution rules which could not be otherwise achieved. ${ }^{202}$ Though that may sound very much like imposing an objective request, the final sentence on the subject concluded that ' $(\mathrm{t})$ he Union legislator enjoys a margin of discretion to make such a determination. ${ }^{203}$ Sapienti sat?

On the whole, it should be taken that both the centralisation of a resolution mechanism and the setting up of an EU agency with centralised implementing powers cumulatively fulfil the two conditions of article 114(1) TFEU.

For that reason, the answer to the first main question is that article 114 TFEU was a valid legal basis for the adoption of the SRM Regulation by which the EU agency 'Single Resolution Board' was established.

Thus, since the answer to the first main question is positive, the answer to the second main question is also necessarily positive because, if article 114 TFEU was a valid legal basis which was used in accordance with the Treaty of Lisbon, it is hard to argue that there is an infraction of the principle of conferral or that this dimension of the transition from a system of EU vertical federalism to a system of EU horizontal federalism has been built on sand.

\footnotetext{
200 ECOFIN (n 193) para 41; Vodafone (n 155).

${ }^{201}$ ECOFIN (n 193) para 41; Vodafone (n 155) para 42.

${ }^{202}$ ECOFIN (n 193) para 42.

${ }^{203}$ ibid, para 142.
} 
One line of reasoning which deals with the issue of the validity of article 114 TFEU in relation to the switch from vertical federalism to horizontal federalism is the one of Andromachi Georgosouli, in which she does not deny the harmonising quality of the SRB's powers, but argues that those powers at the same time 'command to be treated as binding substitutes to decisions made at Member State level', highlighting their 'dual dimension'. ${ }^{204}$ Due to this, she states that 'measures of this type readjust the institutional balance between Member State and EU agencies $^{205}$ (which in the wording of this article is considered as a transition from vertical to horizontal federalism). Consequently, Georgosouli's conclusion is

that the conferral of powers that are anchored with the taking of such measures requires stronger democratic support than the degree of the democratic support afforded by TFEU Article 114. On this view, TFEU Article 352 would have been a more appropriate legal basis for the delegation of such a power. ${ }^{206}$

While dissecting the actions of the EU institutions, one will always be able to find what 'would have been more appropriate', 'would have been better', 'could have been done differently', or 'more wisely'. Even Georgosouli's article focuses more on, inter alia, analysing the possible risks of legal contestation which a regulatory agency like the SRB may encounter and advising on further medium- and long-term reform needed in the operating area of EU agencies than on rebutting the validity of article 114 TFEU.

Therefore, only if the conditions of article 114 TFEU were not satisfied could there have been further investigation of and discussion on whether the principle of conferral and/or transition from vertical to horizontal federalism were under assault. The MSs, by ratifying the Treaty of Lisbon, accepted the possibility that article 114 TFEU would be used for the adoption of measures if its conditions were met, thus EU countries cannot claim that the EU has acted outside its competences since they conferred this competence upon it in the first place. In this instance, due to the satisfied conditions of article 114 TFEU, this is an example of transition from a system of EU vertical federalism to a system of EU horizontal federalism built on a rock. Theorising on the pathways that could have been taken will always be possible, but it is important to separate

\footnotetext{
${ }^{204}$ Andromachi Georgosouli, 'Regulatory Incentive Realignment and the EU Legal Framework of Bank Resolution' (2016) 10(2) Brooklyn Journal of Corporate, Financial \& Commercial Law 343, 371 <http:// brooklynworks.brooklaw.edu/cgi/viewcontent.cgi?article=1216 \&context $=$ bjcfcl $>$ accessed 10 September 2017 .

205 ibid, 377.

206 ibid.
} 
that notion from the conclusion that if one engages in it, the original action must have been invalid in the first place.

\section{Conclusion}

The rain came down, the floods came, and the winds blew, and beat on the EU agency; and the SRB did not fall, for it was founded on a rock. ${ }^{207}$ One can conclude that the EU acted as a wise builder when it built the SRB.

Although, at the start of the research, a great deal of criticism on the establishment of the SRB was found, the authors decided not to take the SRB's surrounding controversy at face value, but rather to dissect and conclude on their own whether the criticism of the founding of such an important EU agency was persuasive or not.

After all the huffing and puffing, after weighing the pro et contra arguments of the Court, the MSs, academia, and the authors' own arguments, the answer is, in fact, positive. Therefore, no matter how prevalent it has been, the criticism is not persuasive. Article 114 TFEU was a valid legal basis for the adoption of the SRM Regulation by which the EU agency 'Single Resolution Board' was established.

Further, this indeed is an example of transition from a system of EU vertical federalism to a system of EU horizontal federalism, and one which is in accordance with the constitutional framework of the EU. In other words, since the conditions of article 114 TFEU needed for its establishment are fulfilled, the Board as an EU supranational tool for a banking market is within the borders of the Treaty of Lisbon. Hence, this particular dimension of the transition is founded on a rock.

Argumentative criticism and open discussion are vital for the development of democratic societies and for the improvement of MS and EU institutions. On the other hand, undeserved and at times exaggerated criticism hurts the EU's cause and hobbles it in reaching its goals by spreading mistrust in EU institutions.

${ }^{207}$ cf Matthew 7:24-27, Revised Standard Version of the Bible. 